\title{
Learning Science through the Arts: The Theory and the Educational Possibilities
}

\author{
Stathis Stivaktakis ${ }^{1}$ Eva Krevetzakis ${ }^{2}$ \\ ${ }^{1}$ School Counselor, Primary Education, Crete, Greece \\ ${ }^{2} \mathrm{PE}$ Teacher, Primary Education, Crete, Greece \\ Doctoral Candidate, University of the Aegean, Rhodes, Greece \\ Email: ststivakt@yahoo.gr
}

\begin{abstract}
The primary purpose of this paper is to highlight the crucial importance of integrating art with science. To do so the paper provides a justification of the inclusion of the arts in the science curriculum, by drawing extensively on both theoretical and empirical work. Thus the paper discusses both the epistemological rationale and the pedagogical rationale behind the integration of art and science. It then provides concrete examples as teaching/learning possibilities with regard to the teaching and learning of science through the arts. The paper makes it quite clear that the inclusion of the arts in the science curriculum can be justified on both epistemological and pedagogical grounds and not simply because the inclusion of the arts makes science learning interesting.
\end{abstract}

Keywords: Teaching science, learning science, art, aesthetic element, integration, engagement, motivation.

\section{Introduction}

Over the past two decades reform efforts in science education have aimed at making school science more humanistic (Hadzigeorgiou, 2005, 2016; Hadzigeorgiou \& Konsolas, 2001). The arts have been considered as important medium through which science teachers can humanize school science. But what is the rationale behind such humanization of school science? Why should the arts be included in the science curriculum in the first place? Can this inclusion be based on the so-called inter/multidisciplinary or integrated approaches to teaching and learning science? And can it be justified solely on the grounds that the arts can make science learning more attractive to the students or even make science learning a creative activity?

According to the literature, art activities offer opportunities for creativity, for identity building (i.e., opportunities for exploring their "unexplored selves"), for self-actualization, opportunities for observation and other scientific skills (e.g., classification), for improvisation and experimentation in a non -threatening environment. In addition, the arts can offer opportunities for kinesthetic, auditory, and visual learners, as well as opportunities for stimulating and exercising a variety of intelligences (see Hadzigeorgiou, 2016). Moreover, given the importance of multi-modal representations for understanding science (Tytler, Prain, Hubber, \& Waldrip, 2013), art-based science activities can provide students with opportunities for both visual representations (e.g., in the form of photos, drawings, models) and enactive representations (e.g., in the form of drama/role play).

However, it is the deeper relationship between art and science that makes the inclusion of the former in the science curriculum indispensable. Indeed, there is work that provides evidence that art and science share a common aesthetic element (Tauber, 1996; Root-Bernstein, 2002). This paper attempts, on the one hand, to shed light on the relationship between art and science - even physical science - and on the notion of beauty in science, thus providing an epistemological rationale for the inclusion of the arts in the science curriculum, and, on the other hand, to discuss, and thus make more evident, the potential of art and science connections to encourage deeper involvement with science - that could be considered the pedagogical rationale. 


\section{The Epistemological Rationale for Integrating Art and Science}

Ever since the persisting gap between the humanities and the sciences was brought forth with Snow's (1959) famous book The Two Cultures, many scholars have discussed the perceived differences between these two fields. However, the need to bring them closer together has also been discussed. This discussion has included the arts, and specifically the similarities between art and science, as such similarities point to their complementary role in our attempt to understand and experience the world (Hadzigeorgiou, 2016). Such complementary role does not necessarily point to a return to a romantic conception of science, which was based upon Friedrich Schlegel's view that "All art should become science and all science art". However, it does point to the importance of an 'aesthetic' kind of understanding, which, as evidence suggests, has played a central role in the work of many scientists (Hadzigeorgiou, 2016).

Nobel laureate Richard Feynman's views, for example, on the nature of science (Feynman, 1989, 1995), do point to such kind of understanding. Stressing, as he did, that not only artists and poets but also scientists can appreciate the beauty of the natural world, Feynman made us focus our attention on how knowledge of science can indeed add to the excitement and mystery experienced by the perception of natural entities and phenomena (Feynman, 1989, p. 11).

The changes that have taken place over the last three decades in the area of the philosophy of science have led us to seriously consider the role of the arts in our attempt to understand the natural world. Kuhn (1970) did point out the importance of aesthetics in the creation of a new scientific theory, while scholars from a variety of scientific fields have explored the common aesthetic element shared by both the arts and the sciences (Tauber, 1996). On the other hand, work in the history of science has also shown that scientific truth seems to be more a matter of a negotiation among the scientists than a search for an objective and absolute truth (Hadzigeorgiou, 2016).

What should be noted is that despite their differences, art and science share a common ground. First, they are both human activities whose motive is to enrich human life. Second, they both, more or less, explore the natural world. Third, like scientists, artists strive for a deeper understanding of the world. Fourth, observation skills are crucially important in both art and science. Fifth, in both fields mental imagery and analogies, and creative imagination in general, play a central role. Sixth, at the moment of creation, the boundaries between art and science cease to exist, and aesthetics play a central role. And seventh, both scientific ideas and works of art help us transform our perception of reality (Hadzigeorgiou, 2016).

According to Kant's theory of knowledge, scientific knowledge becomes possible due to "schematism" while aesthetic judgments are the result of "symbolism". But such distinction was found problematic at the beginning of the 20th century by scientists. Indeed, there was a problem when it came to describing the microcosm, where sense experience cannot provide direct access to knowledge (Heisenberg, 1971). Bohr's approach to the study of the hydrogen atom was similar to that of an artist. Symbolism became central to Bohr's work, and language was used as in poetry by him (Hadzigeorgiou, 2016).

It should be pointed out that it was with the development of quantum physics and the theory of relativity that the distinction between art and science became blurred. Hadzigeorgiou (2016, p. 192) writes:

The unification of time and space, the idea of simultaneity, and the idea that no two observers see exactly the same thing, were common in art and science. The similarities between cubism and the theory of relativity is evidence of these common ideas. For example, with the theory of relativity the concepts of absolute space and time collapsed, while cubism totally demolished the concept of perspective in art.

However, the aesthetic element that is shared between art and science can be seen in the 'artistic' approach to reality and scientific work, in general. According to Root-Bernstein (1996), the scientists "conceive of objects or ideas interchangeably or concurrently in visual, verbal, mathematical, kinesthetic, or musical ways" (p. 66). There is no eminent scientist, according to Root-Bernstein's (1996) research,

[. . .] who simply solves mathematical equations or pours chemicals into test tubes and analyzes the results or catalogues chromosomal abnormalities. Scientists, or at least scientists who are worth their salt, feel what the system they are studying does. They 
transform the equations into images; they sense the interactions of the individual atoms; they even claim to know the desires and propensities of the genes (p. 66).

\section{The Pedagogical Rationale for Integrating Art and Science}

The inclusion of the arts in the science curriculum cannot, and should not, be justified solely on epistemological grounds (i.e., by considering their common aesthetic element). Their inclusion should also be based on a pedagogical rationale. In actual fact, the pedagogical justification of the inclusion of the arts in the science curriculum lies in the possibilities that the arts offer for immersion, prolonged creativity, and change of perception. And while immersion and prolonged creativity address the central and perennial problem of engaging students in science (Hadzigeorgiou \& Stivaktakis, 2008), a change of outlook is considered an important goal of teaching in general and of teaching science in particular (Hadzigeorgiou, 2012, 2017; Hadzigeorgiou \& Schulz, 2014).

Perhaps the most important characteristic of art, which can justify 'pedagogically' the inclusion of the latter in the school curriculum, is its power to charge emotionally that which it depicts. It appears that art is much more likely to do this than mere data, such as tables, numbers, and graphs. An excellent example is the use of satellite visualizations, which can reveal the beauty and the frailty of our planet. Scientific facts, especially those regarding the state of the Earth, such as global warming and its consequences, can be drawn, illustrated in photos, collages, can be dramatized by students themselves (Hadzigeorgiou, 2016).

However, there are a number of specific reasons that make the inclusion of the arts in the school curriculum imperative. And the empirical evidence so far does justify such inclusion. Thus the arts can be justified 'pedagogically' because they have the potential to foster, according to the literature, the following:

1. "Engagement: Art activities encourage deeper involvement because they provide opportunities for anticipation and also for immersion experiences.

2. Creativity: Art activities offer opportunities for "prolonged creativity".

3. Beauty: Art activities offer opportunities for students to appreciate the aesthetic element.

4. Identity building: Art activities, through immersion and creative expression, provide students with opportunities for exploring their "unexplored selves".

5. Self-actualization: Art activities, through self-directed learning and self-expression provide opportunities for self-actualization.

6. Cognitive skills: Art activities offer excellent opportunities for observation and other scientific skills (e.g., classification).

7. Risk taking: Art activities encourage improvisation and experimentation in a non threatening environment.

8. Retention: Arts integration improves long-term memory.

9. Brain growth: Art activities facilitate the creation of neural pathways and the development of stronger synapses.

10. Fine motor skills: Art activities help very young children build the same skills that they use in writing.

11. Learning styles: Art activities can offer opportunities for kinesthetic, auditory, and visual learners.

12. Multiple Intelligences: Art activities offer opportunities for stimulating and exercising a variety of intelligences.

13. Self-Expression: Art activities can help students express not only their thoughts, but also their imagination and their feelings.

14. Change of outlook/perspective: Art activities, by encouraging a more focused way of seeing reality (i.e., through focusing on detail), can facilitate a change in students' perspective/outlook on the world in general"(Hadzigeorgiou, 2016, pp. 194-195). 


\section{Teaching/Learning Possibilities}

It should be noted that making science learning a truly 'artistic' activity is quite challenging. The reason is that a 'truly artistic' activity involves immersion, prolonged creativity and even a change of perception. For it is one thing to design an activity that integrates art and science and another to expect that such an activity can necessarily encourage immersion, creativity and change in students' perception of their object of study (e.g., a natural phenomenon, a natural entity). Nevertheless, there are many possibilities. Depending upon the age of the students, school grade, the available materials, and especially the target concept, the teacher may decide on the most appropriate art form, although all forms can be used with most scientific concepts.

For example, photography and holography, sculpture, drawing and painting, theatre and dance, even poetry, represent ways for introducing scientific ideas through multiple representations. Some specific examples are: Students can work on a project requiring the photographic recording of some (or specific) technological applications and explore the scientific ideas behind them. They can write a poem which includes scientific ideas, draw models, use various materials to make scientific models (e.g., marsh mellows and toothpicks, bottle lids), even study the principles of mechanics through dance (e.g., students, using their own body can illustrate angular momentum transference and conservation). Apparently, computer technology can be an important tool in the hands of both teachers and students. Such an approach to science learning gives students ample opportunities for the development of multiple forms of representation. These representations can be enactive, iconic and symbolic (Bruner, 1966; see also Hadzigeorgiou, Anastasiou, Konsolas, \& Prevezanou, 2009; Tytler et al., 2013).

They can also study the life experiences of great scientists (e.g., Galileo, Newton, Planck, Maxwell, Curie, Bohr, Einstein) in order to develop a script for a play, in which they can dramatize important events from the scientists' lives and work. In such a case, scientific ideas can be included in the script of the play. Of course, such an approach gives students the opportunity to learn ideas about the nature of science. But science content knowledge, if properly included in the script/plot of the play, can be learned too. The dramatization of historical events, implicitly or explicitly, presents scientific ideas anyway (Hadzigeorgiou, 2005, 2016). The best known example of dramatic performance, as regards the history of science, is 'The Blegdamsvej Faust', which was performed in 1932 by Bohr's students (Panditos et al., 2001).

The dramatization of historical events (see Hadzigeorgiou, 2006; Stinner \& Teichmenn, 2003) can also give students the opportunity to study historical debates and controversies (e.g., Lord Kelvin and "The Age of the Earth" debate, the Tesla-Edison and Galvani-Volta controversies), historical experiments (e.g., the Magdeburg experiment, Galileo's experiments), and contemporary socio-scientific issues/controversies (e.g., the use of nuclear energy for the production of electricity; the best way to clean an oil-spill). Such an approach to drama, gives excellent opportunities for learning both ideas about the nature of science and science content knowledge. However, drama activities can also take the form of the enactment of physical entities (e.g., students play the role of molecules in their attempt to illustrate physical changes and natural phenomena). What is now called 'dramatic science' has received, in comparison with other artistic forms, more attention (Odegaard, 2003; McGregor \& Precious, 2015). It is important to point out that dramatization in the form of debates for teaching ideas about the nature of science, is an effective teaching tool for facilitating conceptual change. One of the examples reported by Hadzigeorgiou (2016) is the dramatization that was created by Galileo (in his Dialogues Concerning Two New Sciences) in order to present the arguments between Salviato (representing a Galilean) and Simplicio (representing an Aristotelian), so that students can understand, that both heavy and light bodies, if dropped from the same height above the ground, fall down simultaneously.

Hadzigeorgiou (2016) poses though a question: Can all scientific concepts be presented through some art form? His answer is the following: "This question can be answered in the affirmative, provided we select situations in which the target science concepts are embedded (e.g., the motion of clouds in the case of force, the motion of sea waves in the case of energy). In other words, we need to select phenomena and situations (e.g., a volcano, a tornado, the water cycle, a flash of lightning, the motion of a wave swinger, the twisting somersault or the balancing act of a gymnast), which 'aesthetically' exemplify the target concepts" (Hadzigeorgiou, 2016, pp. 195-196). It is also true, however, that time 
constraints, and some other factors (e.g., learning outcomes) will finally determine which specific art form will be used in the classroom by the teacher, or as part of a home assignment by the students.

In regard to the teaching possibilities, what should also be mentioned is that some art forms can perform specific functions that are important form a pedagogical perspective. Visual arts, for example, like photography, painting and drawing, even sculpture and filmmaking, have the potential - especially nowadays with the educational uses of sophisticated technologies - to raise students' awareness of the beauty of natural entities and phenomena. Images, for example, of water drops and water crystals, snow-flakes, tree leaves, mineral rocks, flashes of lightning, rainbows, light interference patters, can be used to raise an aesthetic awareness. Such visual art forms/products can be used as teaching tools (i.e., both as instructional and assessment tools).

The use of poetry, however, can, and should, be considered. Indeed, poetry can be used because it is a truly imaginative and creative activity (Eastwell, 2002; Watts, 2001), which can spark interest in the beauty and mystery of science (Herrick \& Cording, 2013), it can integrate writing into the science lessons (LaBonty \& Danielson, 2015), it can familiarize students with the nature of science (Frazier \& Murray, 2009). Given the crucial importance of the affective domain in education (Alsop, 2005), the value of poetry in the context of school science should be recognized and seriously considered by science teachers and science educators.

The integration of poetry into school science helps address the two neglected domains in school science education, that is, the affective domain and that of creativity (Yager, 2000). In considering the theory of multiple intelligences (Gardner, 1993; see also Gardner, 1997), and the fact that there are many female students with both high mathematical and high verbal abilities (Wang et al., 2013), poetry can tap the potential of those females, so that they are attracted to science.

However, poetry, in addition to enhancing students' creativity and affective skills, helps foster the ability for imagery, metaphor, and analogy, and also communication. All these skills are crucially important is science and science education. Images, and especially metaphors and analogies, can help one clarify the meaning of scientific ideas.

It deserves to be noted that when students attempt to write a poem, they demonstrate their prior knowledge (i.e., what they already know). It is a misconception to believe that in the process of writing a poem it is only literary skills that are called into play. Science content knowledge comes also into play, as students use such knowledge to illustrate science ideas concepts and phenomena (e.g., forces and motion, light and rainbows, electricity, energy transformations).

Thus poetry in science can be used, according to Hadzigeorgiou (2016), at the beginning of the lesson, as an introduction to the lesson (i.e., to introduce students to the ideas of the lesson), and as way to motivate those with verbal and linguistic ability, and as a culminating activity. It can also be used as an assignment, in which students will try to show what they know about science. Apparently, poems can be written by individual students or in collaboration with their peers, and these poems can be shared in the classroom, followed by discussions about whether these poems do demonstrate scientific understanding.

Dance as well as music can also be considered, as far as teaching/learning opportunities are concerned. It seems that these two art forms can be integrated with other art forms (e.g., the most common integration refers to drama, dance and music), but all forms of art can be integrated into a single activity. According to Hadzigeorgiou (2016), art forms can be combined in order to represent a science concept/idea (e.g., electricity, molecular motion), a phenomenon/process (e.g., the consequences of global warming both in the physical environment, like glacier melting, water level rising, change of landscape, and the human environment, such as change of human geography), to illustrating a natural phenomenon (e.g., the effects of heat or electricity, an earthquake, and water movement/transport, such as sea waves, rain, rivers).

What should also be said with regard to the integration of art forms is that storytelling can facilitate this integration. For example, the "Story of Force", that is, a story about the evolution of ideas from Aristotle, to Galileo, to Newton, can help integrate role play (i.e., students dramatize the scientists), and visual arts (photos and drawing, which can be used to represent the concepts of force and motion), poetry and music, both of which can refer to the laws of motion (Hadzigeorgiou, 2016). 


\section{$5 \quad$ Conclusion and Final Comments}

Recent developments in the epistemology of science, on the one hand, and the consideration of the perennial problem of student engagement in science on the other, make art art/science connections an indispensable component of the school science curriculum. Thus the inclusion of the arts in the science curriculum cannot and should not be justified simply on the ground that it makes science learning interesting. There are both epistemological and pedagogical reasons, according to the analysis carried out in this paper, that justify the inclusion of the arts in the science curriculum and, in general, any instructional decisions to use them in order to foster science learning.

If art can help us escape from the boredom of daily life, as Einstein (1949) himself had observed, and if art has the power to quicken us from "the slackness of routine" and to make us "forget ourselves by finding ourselves in the delight of experiencing the world about us in its varied qualities and forms", as Dewey (1934, p. 110) had eloquently argued, then the role of art and the possibilities it opens for students and teachers should be seriously considered.

For it is a fact, and beyond any doubt, that mainstream science education - with its emphasis, on the one hand, on conceptual understanding (i.e., on students' alternative conceptions and their subsequent restructuring and change), and on standards and international comparisons, on the other has failed to make science learning an engaging and, at the same time, rewarding activity that can make a difference to student's own lives (Hadzigeorgiou, 2014; Hadzigeorgiou \& Garganourakis, 2010). It has been argued that "we often obsess over misconceptions but fail to ask whether students ever apply their 'correct' conceptions outside of school and use them to have aesthetic experiences in the world" (Pugh \& Girod, 2007, p. 10). It is indeed ironic that science curricula give attention to the teaching tools necessary for communicating science ideas and results of scientific investigations, but not to the "aesthetic tools" necessary to actually 'do science'.

Freeman Dyson in his The Scientist as Rebel pointed out that "Science is an art form and not a philosophical method" and that "The great advances in science usually result from new tools rather than from new doctrines" (Dyson, 2008, pp. 17-18). Science as an 'art form', in other words, according to Dyson, reflects the very nature of science. Therefore, 'science as an art form' should complement other ideas about the nature of science, which have received considerable attention by the science education community (Hadzigeorgiou, 2016). Such an idea, in addition to reflecting the nature of science, has the potential to encourage engagement and even deeper involvement with science.

Indeed, the opportunities that art-based activities provide for immersion and prolonged creativity and the change in perception and general outlook that accompanies the experience resulting from the participation in such activities need to be recognized and acknowledged. These educational opportunities constitute the main pedagogical rationale for including the arts in the science curriculum. And the change of students' outlook on science and the world should be considered a significant educational not just instructional -goal. For as the British educational philosopher R.S. Peters argued, in the end, being educated is not about arriving at a destination but about travelling with a different view (Peters, 1973 , p. 20). More empirical evidence for the potential of the arts to foster in students a change of outlook as a result of learning science is certainly needed. However, the recommendation made by RootBernstein deserves particular attention. Following the study of the life experiences of famous scientists, Root-Bernstein recommended that finding ways to integrate art and science in the school curriculum must become a high priority, if we really want to educate students capable of thinking creatively in a science-dominated society (Root-Bernestein \& Root-Bernstein, 2013).

\section{References}

1. Alsop, S. (Ed.) (2005). Beyond Cartesian dualism. Dordrecht, New York: Springer.

2. Bruner, J. (1966). Toward a theory of instruction. New York: Norton.

3. Dewey, J. (1934). Art as experience. New York: Perigee/Penguin Group.

4. Dyson, F. (2008). The scientist as rebel. New York: New York Review Books.

5. Eastwell, P. (2002). Poetry: Adding passion to the science curriculum. Science Education Review, 1, 2.

6. Egan, K. (2005). An imaginative approach to teaching. San Francisco: Jossey-Bass.

7. Einstein, A. (1949). The world as I see it. New York: Philosophical Library. 
8. Feynman, R. (1989). What do you care what other people think? London, UK: Unwin/Hyman.

9. Feynman, R. (1995). Six easy pieces. Reading, Mass: Helix Books.

10.Feynman, R. (2015). The quotable Feynman. Princeton, NJ: Princeton Unversity Press.

11.Frazier, W., \& Murray, K. (2009). Science poetry in two voices: Poetry and the nature of science. School Science Review, 8(2), 58-78.

12.Gardner, H. (1993). Multiple intelligences. The theory in practice. New York: Basic Books.

13.Gardner, H. (1997). Extraordinary minds: Portraits of four exceptional minds and the extraordinary minds in all of us. New York: HarperCollins.

14.Hadzigeorgiou, Y. (2005). On humanistic science education. ERIC DOCUMENT (ED506504).

15.Hadzigeorgiou, Y. (2006). Humanizing the teaching of physics through storytelling: The case of current electricity. Physics Education, 41, 42-46.

16.Hadzigeorgiou, Y. (2012). Fostering a sense of wonder in the science classroom. Research in Science Education, 42, 985-1005.

17.Hadzigeorgiou, Y. (2014). Reclaiming the value of wonder in science education. In K. Egan, A. Cant, \& G. Judson (Eds.), Wonder-full education: The centrality of wonder in teaching and learning across the curriculum (pp. 40-66). New York: Routledge.

18.Hadzigeorgiou, Y. (2016). Imaginative science education. Cham: Switzerland: Springer International.

19.Hadzigeorgiou, Y., \& Konsolas, M. (2001). Global problems and the curriculum: Toward a humanistic and constructivist science education. Curriculum \& Teaching, 16, 29-39.

20.Hadzigeorgiou, Y., \& Fotinos, N. (2007). Imaginative thinking and the learning of science. Science Education Review, 6, 15-22.

21.Hadzigeorgiou, Y., \& Stivaktakis, S. (2008). Encouraging Involvement with School Science. Journal of Curriculum \& Pedagogy, 5, 138-162.

22.Hadzigeorgiou, Y., \& Garganourakis, V (2010). Using Nikola Tesla's story and experiments, as presented in the film "The Prestige", to promote scientific inquiry. Interchange, 41, 363-378.

23.Hadzigeorgiou, Y., Anastasiou, L., Konsolas, M., \& Prevezanou, B. (2009). A study of the effect of preschool children's participation in sensorimotor activities on their understanding of the mechanical equilibrium of a balance beam. Research in Science Education, 39, 39-55.

24.Hadzigeorgiou, Y. \& Schulz, R. (2014). Romanticism and romantic Science: Their contribution to science education. Science \& Education, 23, 1963-2006.

25.Heisenberg, W. (1971). Physics and beyond. London: Allen \& Unwin.

26.Herrick, R., \& Cording, R. (2013). Using a poetry reading on hemoglobin to enhance subject matter. Journal of Chemical Education, 90, 215-218.

27.Kuhn, T. (1970). The structure of scientific revolution. Chicago: University of Chicago Press.

28.LaBonty, J., Danielson, K.E. (2005). Writing poems to gain deeper meaning in science. Middle School Journal, $36(5), 30-36$.

29.McGregor. D., \& Precious, W. (2015). Dramatic science. London: Routledge.

30.Miller, A. (2001). Einstein, Picasso: Space, time, and the beauty that causes havoc. New York: Basic Books.

31.Ødegaard, M. (2003). Dramatic science. A critical review of drama in science education. Studies in Science Education, 39, 75-101.58.

32.Pantidos, P., Spathi, K., \& Vitoratos, E. (2001). The use of drama in science education: The case of 'Blegdamsvej Faust'. Science \& Education, 10, 107-117.42-46.

33.Peters, R.S. (1973). Aims of education: A conceptual enquiry. In R. S. Peters (Ed.), The Philosophy of Education (pp. 1-35). Oxford: Oxford University Press.

34.Pugh, K., \& Girod, M. (2007). Science, art and experience: Constructing a science pedagogy from Dewey's aesthetics. Journal of Science Teacher Education, 18, 9-27.

35.Root-Bernstein, R. (1996). The sciences and arts share a common creative aesthetic. In A. Tauber (Ed.), The elusive synthesis. Aesthetics and science (pp. 49-82). Boston, London: Kluwer.

36.Root-Bernstein, R., \& Root-Bernstein, M. (2013). The art and craft of science. Educational Leadership, 70(5), 16-21.

37.Snow, C. (1959). The two cultures and the scientific revolution. London: Cambridge University Press. 
38.Stinner, A., \& Teichmann, J (2003). Lord Kelvin and the age-of- the-Earth debate: A dramatization. Science \& Education, 12, 213-228.

39.Tauber, A. (Ed.) (1996). The elusive synthesis: Aesthetics and science. Boston and London: Kluwer.

40.Tytler, R., Prain, V., Hubber, P., Waldrip, B. (Eds.) (2013). Constructing representations to learn science. Rotterdam, The Netherlands: Sense Publishers.

41.Vygotsky, L. S. (2004). Imagination and creativity in childhood. Journal of Russian and East European Psychology, 42(1), 7-97 (Original work published 1930).

42.Wang, M., Eccles, J., \& Kenny, S. (2013). Not lack of abilities but lack of choice: Individual and gender differences in choice of careers in science, technology, engineering, and mathematics. Psychological Science, 14, 16.

43.Watts, M. (2001). Science and poetry: passion v. prescription in school science? International Journal of Science Education, 23, 197-208.

44.Yager, R. (2000). What the future vision for science education should be like for the first 25 years of the new millennium. School Science \& Mathematics, 100, 327-341.

45.Yokoi, C., \& Yee, B. (2011). The art and science of notebooks. Science and Children, 49, 42. 